\title{
Survival and growth of Vibrio cholerae and Escherichia coli in treated groundwater consumed in northern Cameroon
}

\author{
Moussa Djaouda ${ }^{1} \cdot$ Zoua Wadoubé $^{2} \cdot$ Odile Baponwa $^{1} \cdot$ Soumayyata Youssoufa ${ }^{1} \cdot$ Bouba Gaké $^{3} \cdot$ Song Liang ${ }^{4,5}$. \\ Moïse Nola ${ }^{6}$
}

Received: 7 July 2018 / Accepted: 10 November 2020 / Published online: 19 November 2020

(c) The Author(s) 2020

\begin{abstract}
Treated groundwater is a major source of drinking water but subject to potential contamination of fecal-oral pathogens. To understand ecology of the pathogens in the treated water, this study evaluated survival and growth of Vibrio cholerae and Escherichia coli in the treated groundwater in northern Cameroon. E. coli and V. cholerae O1 were isolated from human feces. Water samples were collected from the following sources: a well, tap water from the Cameroon Water Utilities Company, and mineral and borehole waters sold in Maroua, respectively. These waters were treated by one or more processes, including autoclaving, filtration, chlorination and ozonation and were used for the constitution of microcosms. E. coli and $V$. cholerae were inoculated into each microcosm at respective concentrations of $50 \mathrm{CFU} / 10 \mathrm{~mL}$ (separately) and $40 \mathrm{CFU} / 10 \mathrm{~mL}$ each (together). All bacterial strains survived in all microcosms were used. The ability to survive and grow varied with the bacterial strain and microcosm $(P<0.05)$. When inoculated separately into the same type of microcosms, $V$. cholerae grew faster than $E$. coli with the latter even showing decrease in concentration in mineral water. When inoculated together, $V$. cholerae grew faster than E. coli, except in autoclaved well water and filtered and autoclaved well water. Autochthonous ultramicroflora inhibited the growth of $E$. coli in filtered well water $(P<0.05)$.
\end{abstract}

Keywords Vibrio cholerae $\cdot$ Escherichia coli $\cdot$ Drinking water $\cdot$ Northern Cameroon

\section{Introduction}

Drinking unsafe water is one of main causes of many waterborne diseases, especially in developing countries (Nanfack et al. 2014). According to the World Health Organization,

Moussa Djaouda

djoubei@gmail.com

1 Higher Teachers' Training College, University of Maroua, PO Box 55, Maroua, Cameroon

2 Faculty of Science, University of Maroua, PO Box 814, Maroua, Cameroon

3 Centre Pasteur du Cameroun, Annexe de Garoua, B.P. 921, Garoua, Cameroon

4 Emerging Pathogens Institute, University of Florida, Gainesville, FL 32610, USA

5 Department of Environmental and Global Health, College of Public Health and Health Professions, University of Florida, Gainesville, FL 32610, USA

6 Laboratory of General Biology, University of Yaoundé I, PO Box 812, Yaoundé, Cameroon unsafe drinking water is responsible for $70 \%$ of waterborne diseases in developing countries (2013).

In Cameroon, diarrheal disease is responsible for $15-20 \%$ of total human deaths per year (Ngwe and Banza-Nsungu 2007). On average, only, $13.5 \%$ of population living in rural areas and $17 \%$ of population in urban areas have access to improved drinking water (BAD 2010). The poor supply of potable water is due to many reasons, primarily uncontrolled urbanization, extreme poverty of the population, and insufficient funds from the public authorities (UN-Habitat 2001). The majority of the population must therefore find ways and means to cope with this challenge (GWP 2010). According to a survey by the INS (2013), $90.2 \%$ of the population living in the city of Yaounde (capital of Cameroon) have access to treated water (72.7\% to tap water, $14.3 \%$ to public tap water, and $3.2 \%$ to mineral water). The rest $9.8 \%$ use protected $(3.8 \%)$ and unprotected $(2.2 \%)$ springs, boreholes (3.2\%), and well waters $(0.6 \%)$.

For more than a decade, cholera epidemics have been recorded every two years in the Lake Chad Basin spanning northern Cameroon, Chad, Nigeria and Niger (Kaas 
et al. 2016; UNICEF 2016). Between 2004 and 2013, 46,172 cholera cases were reported in Cameroon with 979 deaths in the Far North Region (Momba and El-Liethy 2017; UNICEF 2013). According to the WHO (2011), consuming treated water reduces the risk of waterborne diseases such as dysentery and cholera. During the cholera outbreaks, medical authorities usually recommend that people use tap water, mineral water, or disinfect well and borehole waters by chlorination, filtration and/or boiling. Emphasis is also placed on promoting hygienic practices to reduce contamination of water supplies and foods by the fecal-oral pathogens (UNICEF 2016).

Traditionally, drinking water, regardless of its sources, treated or not, is stored in individual households for daily use. Yet, the stored water is subject to contamination by the microorganisms at different points thereby their growth in the water (Djaouda et al. 2010, 2013; Burkowska-But et al. 2015). The quality of stored water is affected by different factors such as water source, container characteristics, duration and condition of storage, conditions of transportation from its source, and non-compliance with hygienic measures (Ngnikam et al. 2007; Djaouda et al. 2010). The survival of fecal bacteria (e.g., E. coli, Salmonella sp., and V. cholerae) in treated well water would depend on the bacterial strain and water treatment applied (Djaouda et al. 2013).

In general, among the microorganisms typically present in water of tropical environments, main pathogenic bacteria include E. coli O157-H7, V. cholerae, Salmonella spp. and Shigella spp. (WHO 2013). During a cholera outbreak, occurrence of fecal contamination of stored water could come with finding of $V$. cholerae and commensal enteric bacteria such as E. coli in the water. Although previously treated, such water could contribute to the spread of the epidemic. Treated water, stored in households, may be contaminated by fecal bacteria during cholera outbreaks. Many fecal bacteria are likely to remain in the water and be responsible for a gradual deterioration of water quality. Accidental contamination of water supply can occur following repairs on the distribution system and, if this is associated with pathogenic $V$. cholerae, a cholera outbreak can happen. Few studies focused on the ecology of pathogenic V. cholerae $\mathrm{O} 1$ in water sources and analysed its role in cholera transmission through its interaction with abiotic factors (Islam et al. 2020). However, very few data are available on the survival and growth of fecal bacteria in treated groundwater in northern Cameroon. In addition, in the event of treated water contamination, the dynamics of $V$. cholerae and commensal enteric bacteria such as $E$. coli remain largely unknown. This information is crucial because the transmission of cholera is plausibly mediated by the survival of $V$. cholerae in treated water contaminated during handling and storage.
The objective of this research was to evaluate the survival and growth of E. coli and V. cholerae in treated groundwater, including tap, well, mineral and borehole sources.

\section{Materials and methods}

\section{Study site}

Northern Cameroon is located between $9^{\circ}$ and $13^{\circ}$ north latitude and between $13^{\circ}$ and $15^{\circ}$ east longitude with fairly varied terrain consisting of plains and mountains. This region has a typical Sudano-Sahelian climate with two distinct seasons: the rainy season from May to September and the dry season from October to April (M'Biandoun et al. 2003; Ndongo et al. 2015). Rainfall is extremely variable with an annual average not exceeding $1000 \mathrm{~mm}$. The temperature varies between 18 and $41^{\circ} \mathrm{C}$ (Sighomnou 2004).

In this region, groundwater is the main source for drinking (Djaouda et al. 2014; Healy Profitós et al. 2016). The public water distribution system uses chlorinated groundwater. For those without access to chlorinated tap water, wells or boreholes serve as the main water source. Wells' depth is comprised between $2.3-10 \mathrm{~m}$, and these water sources serve $34 \%$ of the population (Zoua et al. 2020). Before drinking, well water is usually treated by filtration and/or boiling by few poor households that are advised on the health risks related to unsafe water. The bottled mineral water is much more expensive and usually consumed by the richer households because of concerns over potential risk of the tap water and its organoleptic quality (particularly the taste).

\section{Choice of water types for the study}

Tap, well, borehole, and mineral waters were chosen because of their wide use for drinking and domestic purposes. The borehole and mineral waters were, respectively, treated by ozonation and ozonation followed by chlorination. Tap water was treated by chlorination $(0.1 \mathrm{mg} / \mathrm{L}$ residual chlorine $)$. Well water was treated by physical disinfection techniques (filtration and/or autoclaving).

\section{Water sampling}

Before taking sample from the taps, water was flushed for 5 min and then the mouth of the hand pipe was sterilized with a spirit of lamp flame and then cooled by running water. Samples were collected from wells, and flasks were filled in the same way as people normally use to fill their water containers. Bottled borehole and mineral waters in $1.5 \mathrm{~L}$ bottles were purchased at the Central Market of Maroua and immediately transported to the laboratory at ambient temperature $\left(24^{\circ} \mathrm{C}\right)$. 


\section{Choice of bacterial strains}

$E$. coli and $V$. cholerae were selected for their importance in the environment and public health. E. coli is an excellent indicator of fecal contamination of water (Edberg et al. 2000; Chippaux et al. 2002; Valenzuela et al. 2009). V. cholerae $\mathrm{O} 1$ has been the cause of recent cholera outbreaks in northern Cameroon. The E. coli strain was isolated in the laboratory from human feces. Its identification was made according to the techniques described by Holt et al. (2000). The strain of $V$. cholerae $\mathrm{O} 1$ was obtained from the Pasteur Center of Cameroon. The biochemical and serological tests were used for confirmation of the bacterial strain (CDC 2015).

\section{Preparation of bacterial stocks}

For the preparation of bacterial stocks, a colony forming unit of either E. coli and V. cholerae from standard agar medium was inoculated into $100 \mathrm{~mL}$ of nutrient broth for $24 \mathrm{~h}$ at $37^{\circ} \mathrm{C}$. The strain of $V$. cholerae was grown on alkaline nutrient agar and $E$. coli on standard non-selective plate count agar (Bio-Rad) for later use. Cells were then harvested by centrifugation at $3000 \mathrm{~g}$ for $10 \mathrm{~min}$ at ambient temperature and washed twice with sterile $\mathrm{NaCl}$ solution $(8.5 \mathrm{~g} / \mathrm{L})$. The washed cells were suspended in sterile saline for inoculation of studied microcosms.

\section{Microcosms}

Well water samples were treated by filtration $(0.22 \mu \mathrm{m})$ and/ or autoclaving at $121{ }^{\circ} \mathrm{C}$ for $15 \mathrm{~min}$. Borehole, mineral and tap water, disinfected at the industry level, did not undergo any additional treatment. Seven types of microcosms were performed: sterile saline (SS), filtered well water (FWW), autoclaved well water (AWW), filtered-autoclaved well water (FAWW), chlorinated tap water (CTW), ozonated borehole water (OBW) and mineral water (MW) treated by ozonation and chlorination. For each type of treated water, three microcosms of $100 \mathrm{~mL}$ each were made in flasks.

\section{Bacteriological control of microcosms}

A microbiological quality control of the different microcosms was carried out before inoculation of the bacterial strains. $10 \mathrm{~mL}$ of each type of treated water was collected and analyzed, using the membrane filtration technique and the EMB (Eosine Methylene Blue) agar (Abteck Biologicals Laboratries, Liverpool, England) for E. coli and TCBS (Thiosulfate Citrate Biles Salts Sucrose agar) (Merck KGaA, Darmstadt, Germany) for V. cholerae seeking (APHA 2012). All analyses were repeated three times. The water samples with no these microorganisms found were used for the constitution of the microcosms.

\section{Inoculation of microcosms}

To approach the natural conditions of bacterial contamination of water, the various microcosms were contaminated by bacterial suspensions in saline solution. One hundred microliters of water from each microcosm (flask of $100 \mathrm{~mL}$ water) was removed and replaced with $100 \mu \mathrm{L}$ of bacterial suspension. A first series of different microcosms was contaminated at level of $50 \mathrm{CFU} / 10 \mathrm{~mL}$ of $E$. coli, a second series at $50 \mathrm{CFU} / 10 \mathrm{~mL}$ of $V$. cholerae. The third set was contaminated with both $40 \mathrm{CFU} / 10 \mathrm{~mL}$ E. coli and $40 \mathrm{CFU} / 10 \mathrm{~mL}$ V. cholerae. The bacterial concentrations used for the inoculation of microcosms were inspired by those usually observed under natural conditions in the study area (Djaouda et al. 2014). Flasks were then incubated without shaking, in the dark, at room temperature $\left(30 \pm 2{ }^{\circ} \mathrm{C}\right)$ in a similar way to Elmahdy et al. (2018).

\section{Evaluation of the survival and growth of $V$. cholerae and $E$. coli in water microcosms}

The local people use containers that allow water storage for up to three days, but normally households store the water for $24 \mathrm{~h}$ (Djaouda et al. 2013). For this reason, our study used one day as observation time unit. The initial bacterial concentration of $V$. cholerae and $E$. coli was immediately determined after contamination of the microcosms (J0). The water storage lasted for three days, and analyses were performed after $24 \mathrm{~h}, 48 \mathrm{~h}$, and $72 \mathrm{~h}$ (J3) to determine bacterial concentrations. Experiments were done thrice. Bacterial cultures were incubated at $37{ }^{\circ} \mathrm{C}$. The membrane filtration technique (APHA 2012) was used to enumerate $E$. coli and $V$. cholerae in ten millilitres of raw or diluted water sample from each microcosm. Plate count agar (PCA) and alkaline nutrient agar were used to enumerate E. coli and $V$. cholerae, respectively. In order to determine its potential influence on the survival and growth of V. cholerae and E. coli, concentration of autochthonous ultramicroflora was simultaneously determined on PCA in FWW microcosm. It was found difficult to distinguish colonies of the experimental bacteria from those of the autochthonous ultramicroflora on PCA. Therefore, $0.22 \mu \mathrm{m}$ filtered FWW water was used for enumeration of autochthonous ultramicroflora on PCA. Expression of bacterial concentration was given in colony forming unit (CFU) per volume of water. 


\section{Data analysis}

The variations in bacterial concentrations as a function of time in each microcosm were explored using the Sigmaplot 10.0 software. Due to their skewed distributions, the bacterial counts (x) were log-transformed (Daumas 1982). Two nonparametric tests (Kruskal-Wallis and Wilcoxon) were performed to investigate whether there was any difference in the median concentration of $E$. coli and $V$. cholerae among different microcosms and water storage periods using $\mathrm{R}(\mathrm{R}$ Core Team, Version 3.6.3). The Spearman correlation test to determine the relation between the autochthonous ultramicroflora and the experimental fecal bacteria was performed using also R (R Core Team, Version 3.6.3).

\section{Results}

\section{Dynamics of concentration of V. cholerae and E. coli inoculated separately in microcosms}

Variations in the concentrations of V. cholerae and E. coli, inoculated separately into each microcosm type, for the three days period of water storage, are shown in Fig. 1.

\section{Escherichia coli}

Overall, the concentration of E. coli increased from J0 to $\mathrm{J} 3$ in all microcosms, except for mineral water (MW) (Fig. 1). The median concentration of $E$. coli increased from J0 (1.71 $\log _{10} \mathrm{CFU} / 10 \mathrm{~mL}$ ) to J3, considering saline (SS) (3.84 $\log _{10} \mathrm{CFU} / 10 \mathrm{~mL}$, interquartile range $\left.(\mathrm{IQR})=1.46\right)$, tap water $(\mathrm{CTW})\left(1.78 \log _{10} \mathrm{CFU} / 10 \mathrm{~mL}, \mathrm{IQR}=1.11\right)$, well water $(\mathrm{AWW})\left(2.08 \log _{10} \mathrm{CFU} / 10 \mathrm{~mL}, \mathrm{IQR}=1.69\right)$ and filtered and autoclaved well water (FAWW) (2.80 $\left.\log _{10} \mathrm{CFU} / 10 \mathrm{~mL}, \mathrm{IQR}=2.18\right)$, borehole water $(\mathrm{OBW})$ $\left(1.87 \log _{10} \mathrm{CFU} / 10 \mathrm{~mL}, \mathrm{IQR}=2.00\right)$ and filtered well water $(\mathrm{FWW})\left(1.72 \log _{10} \mathrm{CFU} / 10 \mathrm{~mL}, \mathrm{IQR}=2.18\right)$ microcosms. On the other hand, the median concentration of E. coli in the mineral water microcosm (MW) decreased from $\mathrm{J} 0$ to $\mathrm{J} 3\left(0.90 \log _{10} \mathrm{CFU} / 10 \mathrm{~mL}, \mathrm{IQR}=0.66\right)$.

\section{Vibrio cholerae}

The median concentration of $V$. cholerae increased from $\mathrm{J} 0$ (1.71 $\log _{10} \mathrm{CFU} / 10 \mathrm{~mL}$ ) to $\mathrm{J} 3$, resulting in a median concentration of $2.59 \log _{10} \mathrm{CFU} / 10 \mathrm{~mL}(\mathrm{IQR}=0.19), 3.42$ $\log _{10} \mathrm{CFU} / 10 \mathrm{~mL}(\mathrm{IQR}=0.59), 2.17 \log _{10} \mathrm{CFU} / 10 \mathrm{~mL}$ $(\mathrm{IQR}=0.54), 2.29 \log _{10} \mathrm{CFU} / 10 \mathrm{~mL}(\mathrm{IQR}=0.58)$ for the microcosms FWW (Fig. 1f), MW (Fig. 1b), AWW (Fig. 1d) and FAWW (Fig. 1e), respectively. During the three days of water storage in the microcosm CTW, a small increase in $V$. cholerae concentration was noted (from $1.71 \log _{10} \mathrm{CFU} / 10 \mathrm{~mL}$ to median concentration 2.35 $\log _{10} \mathrm{CFU} / 10 \mathrm{~mL}, \mathrm{IQR}=0.58$ ) (Fig. 1c). In the microcosms OBW (Fig. 1g) and SS (Fig. 1a), V. cholerae concentration increased rapidly from $\mathrm{J} 0$ to $\mathrm{J} 3$ (from $1.71 \log _{10} \mathrm{CFU} / 10 \mathrm{~mL}$ to median concentration $3.15 \log _{10} \mathrm{CFU} / 10 \mathrm{~mL}, \mathrm{IQR}=0.95$ and from $1.71 \log _{10} \mathrm{CFU} / 10 \mathrm{~mL}$ to median concentration $3.16 \log _{10} \mathrm{CFU} / 10 \mathrm{~mL}, \mathrm{IQR}=0.26$, respectively). Overall, concentration of $V$. cholerae increased in all microcosm waters during the three days of water storage. However, this increase was lower in CTW microcosm.

\section{Dynamics of concentration of $V$. cholerae and $E$. coli inoculated together in microcosms}

Variations in the concentration of V. cholerae and E. coli, inoculated together into each microcosm type, for the three days period of water storage are presented in Fig. 2.

The median concentration of $E$. coli slightly increased from J0 $\left(1.61 \log _{10} \mathrm{CFU} / 10 \mathrm{~mL}\right)$ to $\mathrm{J} 3$, resulting in a median concentration of $1.66 \log _{10} \mathrm{CFU} / 10 \mathrm{~mL}(\mathrm{IQR}=0.52)$ and $1.63 \log _{10} \mathrm{CFU} / 10 \mathrm{~mL}(\mathrm{IQR}=0.94$ ) for the microcosms MW (Fig. 2b) and AWW (Fig. 2d), respectively. More increase in $E$. coli concentration was observed in the microcosms SS, OBW and FAWW, varying from $1.61 \log _{10} \mathrm{CFU} / 10 \mathrm{~mL}$ (J0) to $2.64 \log _{10} \mathrm{CFU} / 10 \mathrm{~mL}$ (IQR $=0.72$ ), $2.06 \log _{10} \mathrm{CFU} / 10 \mathrm{~mL}$ $(\mathrm{IQR}=0.88)$ and $2.41 \log _{10} \mathrm{CFU} / 10 \mathrm{~mL}(\mathrm{IQR}=0.51)(\mathrm{J} 3)$, respectively. On the other hand, the median concentration of $E$. coli in the CTW and FWW microcosms decreased from J0 to J3 $\left(1.34 \log _{10} \mathrm{CFU} / 10 \mathrm{~mL}, \mathrm{IQR}=0.58\right)$ and 0.84 $\log _{10} \mathrm{CFU} / 10 \mathrm{~mL}, \mathrm{IQR}=0.95$, respectively).

Overall, the concentration of $V$. cholerae increased from $\mathrm{J} 0$ to $\mathrm{J} 3$ in all microcosms, except for AWW and FAWW microcosms (Fig. 2). The median concentration of $\mathrm{V}$. cholerae increased from $\mathrm{J} 0\left(1.61 \log _{10} \mathrm{CFU} / 10 \mathrm{~mL}\right)$ to $\mathrm{J} 3$, considering saline (SS) $\left(2.10 \log _{10} \mathrm{CFU} / 10 \mathrm{~mL}, \mathrm{IQR}=0.91\right)$, mineral water (MW) $\left(2.06 \log _{10} \mathrm{CFU} / 10 \mathrm{~mL}, \mathrm{IQR}=0.92\right)$, tap water (CTW) (2.02 $\left.\log _{10} \mathrm{CFU} / 10 \mathrm{~mL}, \mathrm{IQR}=0.81\right)$, borehole water $(\mathrm{OBW})\left(2.32 \log _{10} \mathrm{CFU} / 10 \mathrm{~mL}, \mathrm{IQR}=0.65\right)$ and filtered well water $(\mathrm{FWW})\left(1.85 \log _{10} \mathrm{CFU} / 10 \mathrm{~mL}, \mathrm{IQR}=0.41\right)$ microcosms. In FAWW, $V$. cholerae median concentration slightly decreased on $\mathrm{J} 3$ to $1.56 \log _{10} \mathrm{CFU} / 10 \mathrm{~mL}$ $(\mathrm{IQR}=0.14)$. For the microcosm AWW (Fig. 2d), during the three days of water storage, the concentration of $\mathrm{V}$. cholerae remained almost unchanged $\left(1.61 \log _{10} \mathrm{CFU} / 10 \mathrm{~mL}\right.$, $\mathrm{IQR}=0$ ). These results indicated a weak growth of $\mathrm{V}$. cholerae in autoclaved water (AWW, FAWW) after three days of water storage.

\section{Relation between autochthonous ultramicroflora, $E$. coli and $V$. cholerae inoculated in filtered well water}

The relation between autochthonous ultramicroflora, E. coli and $V$. cholerae inoculated separately or together in filtered 

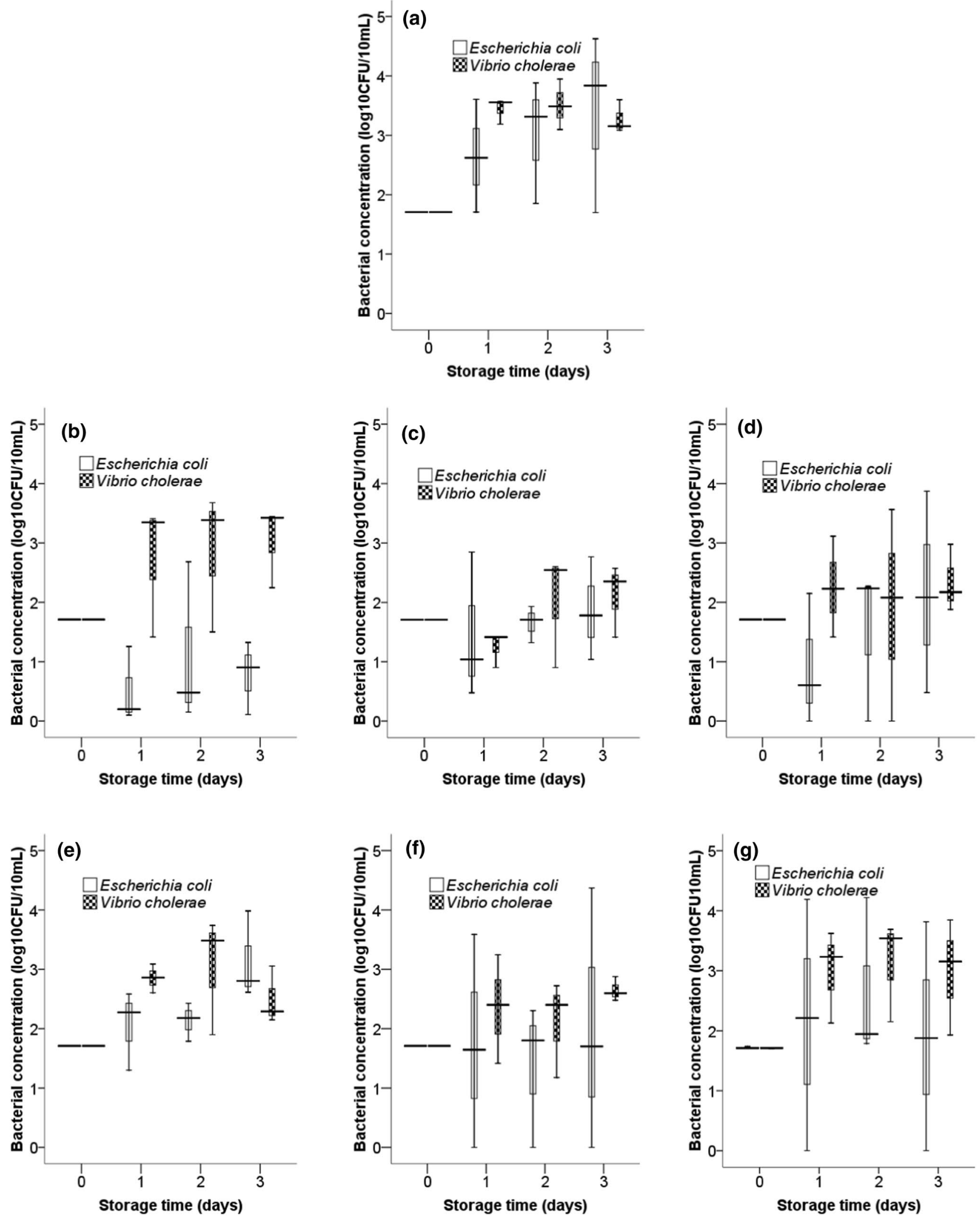

Fig. 1 Variations in concentrations of E. coli and V. cholerae inoculated separately in sterile saline a, mineral water $\mathbf{b}$, chlorinated tap water $\mathbf{c}$, autoclaved well water $\mathbf{d}$, filtered-autoclaved well water $\mathbf{e}$, filtered well water $\mathbf{f}$ and ozonated borehole water $\mathbf{g}$ during storage (Boxplot, $n=3$ ) 

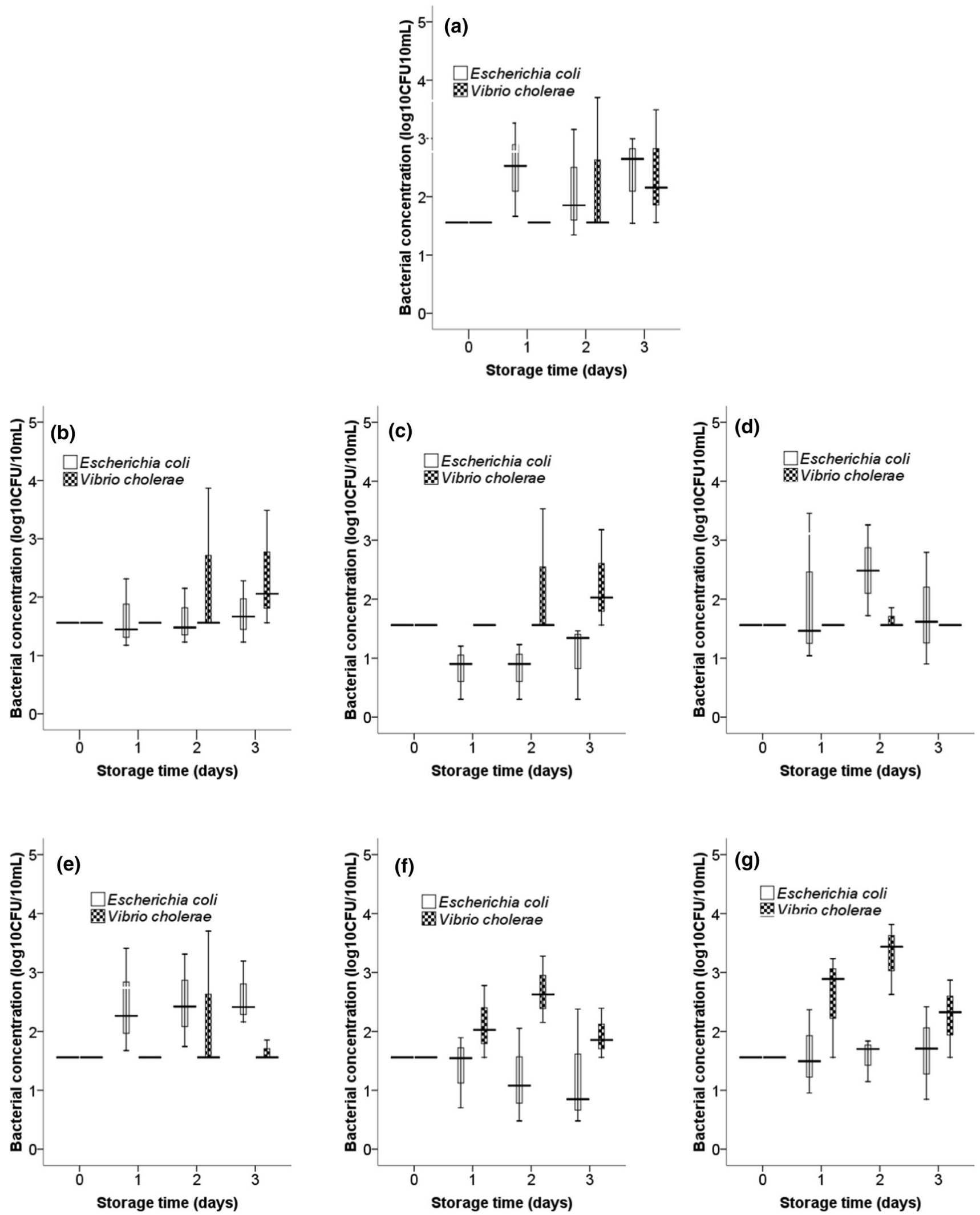

Fig. 2 Variations in concentrations of E. coli and V. cholerae inoculated together in sterile saline a, mineral water $\mathbf{b}$, chlorinated tap water $\mathbf{c}$, autoclaved well water $\mathbf{d}$, filtered-autoclaved well water $\mathbf{e}$, filtered well water $\mathbf{f}$ and ozonated borehole water $\mathbf{g}$ during storage (Boxplot, $n=3$ ) 
well waters was examined by the Spearman correlation test. Concentration of ultramicroflora in filtered well water was not significantly correlated with E. coli and $V$. cholerae when these bacteria were inoculated separately into the medium. However, increasing autochthonous ultramicroflora in filtered well water would not inhibit the growth of $V$. cholerae and E. coli. The population increase in autochthonous ultramicroflora was negatively correlated with $E$. coli and positively to $V$. cholerae when these bacteria were inoculated together into filtered well water $(P<0.05)$. The decay of $E$. coli influenced by the presence of autochthonous ultramicroflora would be favorable for the multiplication of $V$. cholerae in the medium.

\section{Discussion}

\section{Variations of concentration of V. cholerae and $E$. coli inoculated separately in microcosms}

\section{E. coli}

The concentration of E. coli, inoculated alone, increased from J0 to J3 in all microcosms, except for the MW microcosm, where this concentration decreased during storage of water. The Kruskal-Wallis test showed that at least one of the microcosms presented a median concentration of $E$. coli that was significantly different $(P<0.05)$. The concentration of $E$. coli underwent significant variations depending on the types of treated water. This variability was also noted by Djaouda et al. (2013) in a previous study. Wilcoxon test showed that $E$. coli concentration was significantly lower in mineral water than in saline $(P<0.05)$. The decrease in the concentration of $E$. coli in the mineral water was likely related to the water treatment techniques. Indeed, the chlorination following ozonation during the production of mineral water ensures long-term disinfection due to residual chlorine (Vital 2010; Goncharuk 2014).

Concentration of $E$. coli was significantly higher in saline than in tap water $(P<0.05)$. The low growth of $E$. coli in tap water was likely due to the combination of several factors. Directly after the water chlorination, E. coli cells are usually killed or inactivated (Al-Bahry et al. 2014). However, the growth of $E$. coli was weakly inhibited during the storage of tap water. According to Al-Bahry et al. (2014) and LeChevallier (2003), the effect of chlorine on bacteria decreases over time due to its interaction with other chemical elements in the water.

There was a statistically significant difference between borehole water $(\mathrm{OBW})$ where there was a large increase in $E$. coli concentration and mineral water (MW) where there was a decrease in this concentration $(P<0.05)$. The treatment of water by ozonation as in the case of borehole water would not guarantee the protection of water from further bacterial contamination. Bouteleux (2005) showed that the treatment of water by ozonation does not affect the growth of $E$. coli in case of further contamination. The combination of chlorination and ozonation, however, provided effective protection of the mineral water. These results corroborate those of Bouteleux (2005) and Serrano et al. (2012) who showed that the concentration of $E$. coli decreases in mineral water after $24 \mathrm{~h}$ of storage.

\section{Vibrio cholerae}

The Kruskal-Wallis test showed that at least one of the microcosms presented a median concentration of $V$. cholerae that was significantly different $(P<0.05)$. The results of this study showed a weak growth of $V$. cholerae in filtered well water (FWW) compared to physiological saline (SS) and borehole water (OBW) $(P<0.05)$. Djaouda et al. (2013) also showed an inhibition of $V$. cholerae growth in filtered well water during its storage. Moreover, filtration also reduces a large quantity of the particles present in the water (Vital 2010), although, during filtration, a fraction of the autochthonous microflora (ultramicroflora) is able to pass through the pores of the filter apparatus (Hahn 2004). This ultramicroflora is likely to grow using natural organic carbon available in water. The competition between autochthonous ultramicroflora and $V$. cholerae cells for the same vital resource would thus be at the origin of this weak growth of $V$. cholerae in filtered well water.

However, the comparison of the median values did not show significant difference in concentrations of $V$. cholerae between FWW, FAWW and AWW. During autoclaving, a fraction of autochthonous bacteria, that possibly passes through the filter, are destroyed. This destruction would allow the formation of assimilable organic carbon in large quantities, a nutrient essential for the growth of $V$. cholerae (Wang et al. 2007; Vital 2010; Pandit and Kumar 2013; Goncharuk 2014). In FAWW, filtration reduces the amount of organic matter in the water (Soppe et al. 2015). Autoclaving hydrolyzes the remaining organic matter in the previously filtered water with release of assimilable organic carbon (LeChevallier 2003). The availability of assimilable organic carbon is believed to be responsible for the growth of $V$. cholerae. However, the median concentration of $V$. cholerae was significantly higher in saline compared to autoclaved well water and filtered and autoclaved well water $(P<0.05)$. Saline, although not containing organic matter, is able to stabilize $V$. cholerae cells and allow them to grow thanks to their reserves. The results of this study showed that the median concentration of $V$. cholerae was significantly lower in autoclaved well water compared to that of borehole water $(P<0.05)$. Both ozonation and autoclaving result in the hydrolysis of organic matter in the water 
(Pandit and Kumar 2013). Moreover, these two techniques do not guarantee residual protection of the water in the event of further bacterial contamination. The survival and growth of $V$. cholerae in well water, filtered and autoclaved or not, would mostly depend on the physicochemical properties of the water.

Wilcoxon test showed a significant difference between the median concentration of $V$. cholerae between borehole and tap water $(P<0.05)$. That result was in alignment with some other similar studies (Mary et al. 2001; Bouteleux 2005; Serrano et al. 2012). Bouteleux (2005) showed that V. cholerae grows in water treated with ozonation in case of further contamination. As in the case of E. coli, V. cholerae concentration was significantly higher in saline than in tap water $(P<0.01)$. Residual chlorine in tap water was very likely the limiting factor that affects the growth of $V$. cholerae.

The Wilcoxon test revealed higher median concentration of $V$. cholerae in mineral water than in tap water $(P<0.05)$. This could be explained by possible conditions in mineral water reducing the impact of residual chlorine on $\mathrm{V}$. cholerae. Indeed, some ions such as $\mathrm{HCO}_{3}{ }^{-}$and $\mathrm{Na}^{+}$in mineral water might decrease the efficacy of chlorine disinfection by increasing the $\mathrm{pH}$ of the water (McGuire, 2018).

When E. coli and $V$. cholerae were inoculated separately in microcosms, concentration of E. coli remained higher than those of $V$. cholerae in SS and FAWW. This corresponds to one of the criteria (greater ability to survive in water than pathogenic germs) that made it possible to choose E. coli as a bioindicator (Edberg et al. 2000). However, the growth of these bacteria is low in water treated by ozonation and/or chlorination. E. coli would not be a good indicator of contamination of chemically treated water.

\section{Variations of concentration of $V$. cholerae and $E$. coli inoculated together in microcosms}

Overall, concentration of $E$. coli increased slightly in all microcosms except in CTW and FWW where it decreased during water storage. Residual chlorine in tap water would have inhibited the growth of E. coli during water storage (LeChevallier 2003; Vital 2010; String et al. 2020). According to Mary et al. (2001), the survival of allochthonous bacteria such as $E$. coli in filtered water could be reduced by the presence of "ultramicrocells" of autochthonous bacterial microflora, due to nutrient competition exerted by bacteriolytic enzymes of membrane vesicles produced by native microflora.

In all microcosms, concentration of $V$. cholerae remained higher than that of $E$. coli, except in autoclaved well water and filtered and autoclaved well water where $E$. coli concentration was higher. V. cholerae was able to survive in groundwater under storage conditions and even in competition with other microorganisms (Djaouda et al. 2013). The growth of $V$. cholerae in well water autoclaved and filtered or not, as shown precedently when not mixed with $E$. coli, would mostly depend on physicochemical properties of water.

When inoculated together, the median concentration of $V$. cholerae was significantly higher than the median concentration of $E$. coli in microcosms CTW $(P<0.01)$, FWW $(P<0.05)$ and OBW $(P<0.05)$ following $72 \mathrm{~h}$ of storage (J3).

Variations in water physicochemical properties and microcosm type presented different influence on survival and growth of $V$. cholerae and E. coli.

\section{Influence of autochthonous ultramicroflora on dynamics of concentration of $V$. cholerae and $E$. coli inoculated separately in filtered well water}

The Spearman correlation test performed suggests that autochthonous ultramicroflora in filtered well water did not significantly affect $E$. coli and $V$. cholerae when these bacteria were inoculated separately into the medium. According to Messi et al. (2002), E. coli was less able to survive than the autochthonous ultramicroflora and is no longer detectable after several days of water storage. The availability of dissolved nutrients in FWW reduced the influence of the autochthonous ultramicroflora on E. coli growth.

The increase in the autochthonous ultramicroflora population had a significantly negative impact on $E$. coli but not $V$. cholerae when these bacteria were inoculated together into filtered well water. Autochthonous ultramicroflora feeds on organic matter and organic carbon. E. coli feeds mainly on the organic matter present in the water, while $V$. cholerae feeds mainly on assimilable organic carbon. When E. coli and $V$. cholerae are inoculated together, competition between $E$. coli and autochthonous ultramicroflora is unfavorable for E. coli. Dead E. coli cells would constitute organic matter for the autochthonous ultramicroflora. Thus, the proliferation of autochthonous ultramicroflora that feeds on organic matter would be beneficial to $V$. cholerae whose diet is based on organic carbon. Similar results were obtained by Vital (2010) and Bouteleux (2005) with Enterobacteriaceae. According to Djaouda et al. (2013), V. cholerae was able to survive in the presence of autochthonous ultramicroflora cells in stored filtered well water. Jubair et al. $(2012,2014)$ also demonstrated that $V$. cholerae persists even for 700 days in microcosms consisting of nutrient-poor lake waters containing other aquatic microorganisms.

\section{Conclusion}

The tap water, mineral water, and borehole water treated by chlorination, ozonation/chlorination and ozonation, respectively, were overall of good microbiological quality. 
The treatment of well water by filtration, autoclaving, and filtration and autoclaving also contributed to water quality improvement. However, further contamination of any treated water, during home storage, compromised water quality. $E$. coli and $V$. cholerae survived in all treated waters that served as microcosms in this study. Inoculated separately in microcosms, V. cholerae presented higher abundance compared to E. coli, after three days, except in filtered-autoclaved well water. When these microorganisms were inoculated together in the microcosms, $V$. cholerae concentration remained higher than that of $E$. coli except in autoclaved well water and filtered and autoclaved well water where the reverse was noted. E. coli had a relatively lower survival ability than $V$. cholerae in the microcosms where they were inoculated together. In the presence of the autochthonous ultramicroflora, $V$. cholerae can develop in the treated water and is even able to multiply in competition with the ultramicrocells of the autochthonous microflora. The extended survival of $V$. cholerae in treated water may have serious public health implications in northern Cameroon where access to safe water and sanitary hygiene is limited. Chlorination was more effective than other water disinfection techniques. It is recommended that households without access to drinking water should disinfect all drinking water by chlorination and boiling, and keep treated water 'safely' stored to avoid further contamination.

Funding This research was partially supported by the International Foundation for Science, Stockholm, Sweden through a Grant (W/55811) to MOUSSA DJAOUDA.

\section{Compliance with ethical standards}

Conflict of interest The authors declare that they have no conflict of interest.

Open Access This article is licensed under a Creative Commons Attribution 4.0 International License, which permits use, sharing, adaptation, distribution and reproduction in any medium or format, as long as you give appropriate credit to the original author(s) and the source, provide a link to the Creative Commons licence, and indicate if changes were made. The images or other third party material in this article are included in the article's Creative Commons licence, unless indicated otherwise in a credit line to the material. If material is not included in the article's Creative Commons licence and your intended use is not permitted by statutory regulation or exceeds the permitted use, you will need to obtain permission directly from the copyright holder. To view a copy of this licence, visit http://creativecommons.org/licenses/by/4.0/.

\section{References}

APHA (2012) Standard methods for the examination of water and wastewater, vol 22. American Public Health Association/
American Water Works Association/Water Environment Federation, Washington, DC, USA

Al-Bahry SN, Mahmoud IY, Paulson JR, Al-Musharafi SK (2014) Survival and growth of antibiotic resistant bacteria in treated wastewater and water distribution system and their implication in human health: a review. Int Arab J Antimicrob Agents 4(1):1-11

BAD (2010) Projet d'alimentation en eau potable et d'assainissement en milieu rural, Rapport d'évaluation de projet. https://www.afdb. org/fileadmin/uploads/afdb/Documents/Project-and-Operations/ Cameroun_Projet_d\%E2\%80\%99alimentation_en_eau_potab le_et_d\%E2\%80\%99assainissement_en_milieu_rural_-_Rappo rt_d\%E2\%80\%99\%C3\%A9valuation.pdf. Accessed 21 May 2018

Bouteleux C (2005) Survie d'entérobactéries dans les eaux de distribution: rôle de la matière organique d'origine algale, thèse de Doctorat, Université HENRI-POINCARE - NANCY, France

Burkowska-But A, Kalwasinska A, Brzezinska MS (2015) Bacterial growth and biofilm formation in household-stored groundwater collected from public wells. J Water Health 13(2):353-361

CDC (2015) Cholera- Vibrio cholerae infection. Diagnosis and detection. How to diagnose. Rapid test. Centers for Disease Control and Prevention

Chippaux JP, Houssier S, Bouvier C, Brissaud F (2002) Etude de la pollution de l'eau souterraine de la ville de Niamey. Niger Bulletin de la Société de Pathologie Exotique 94(2):119-123

Daumas F (1982) Méthodes de normalisation des données. Revue de Statistique Appliquée 30(4):23-38

Djaouda M, Nola M, Zebaze Togouet SH, Nougang ME, Djah M, Njiné T (2010) Modifications des propriétés d'abondances bactériennes des eaux souterraines en réponse à une longue durée de stockage dans les récipients à domicile à Yaoundé (Cameroun). Eur J Water Qual 41:131-143

Djaouda M, Nola M, Gaké B, Ebang Menye D, Njine T (2011) Faecal contamination of well water in Garoua (Cameroon): importance of household storage and sanitary hygiene. Int J Res Chem Environ 1:97-103

Djaouda M, Gaké B, Ebang Menye D, Zébazé Toguet SH, Nola M, Njiné T (2013) Survival and Growth of Vibrio cholerae, Escherichia coli, and Salmonella spp. in well water used for drinking purposes in Garoua (North Cameroon). Int J Bacteriol. https:// doi.org/10.1155/2013/127179

Djaouda M, Njiné T, Liang S, Ebang Menye D, Gaké B, Zébazé Togouet SH, Nola M (2014) Bacteriological quality of Well Waters in Garoua, North Cameroon. Water Qual Expo Health 6:161-176

Edberg SC, Rice EW, Karlin RJ, Allen MJ (2000) Escherichia coli: the best biological drinking water indicator for public health protection. J Appl Microbiol 88:106S-116S

Elmahdy MEI, Magri ME, Garcia LA, Fongaro G, Barardi CRM (2018) Microcosm environment models for studying the stability of adenovirus and murine norovirus in water and sediment. Int $\mathrm{J}$ Hyg Environ Health. https://doi.org/10.1016/j.ijheh.2018.04.002

Goncharuk VV (2014) Drinking water physics, chemistry and biology. Institute of colloid and water chemistry national academy of sciences of Ukraine Kyiv. Springer, Switzerland, pp 347-350

GWP (2010) Etude sur les sources de financement du secteur de l'eau au Cameroun pour la création d'un FORSEAU, Rapport, Cameroun. https://www.gwp.org/globalassets/global/gwp-caf-files/etude -nationale-sur-le-financement-du-secteur-de-leau-au-cameroun. pdf. Accessed 14 May 2018

Hahn MW (2004) Broad diversity of viable bacteria in "sterile" $0.2 \mu \mathrm{m}$ filtered water. Res Microbiol 155:688-691

Healy-Profitós J, Lee S, Mouhaman A, Garabed R, Moritz M, Piperata B, Lee J (2016) Neighborhood diversity of potentially pathogenic bacteria in drinking water from the city of Maroua Cameroon. J Water Health 14:559-570 
Holt JG, Krieg NR, Sneath PHA, Staley JT, Williams ST (2000) Bergey's Manual of determinative bacteriology, vol 9. Lippincott Williams and Wilkins, Philadephia

INS (2013) Etude pilote sur la pollution des eaux de surface et souterraine à Yaoundé et son impact sur la santé des populations riveraines, Rapport d'enquête, Yaoundé, Cameroun. https://www.bgr. bund.de/EN/Themen/Wasser/Projekte/abgeschlossen/TZ/Kamer un/epess_technrep_small_text.pdf?_blob=publicationFile $\& v=3$. Accessed 15 April 2018

Islam MS, Zaman MH, Islam MS, Ahmed N, Clemens JD (2020) Environmental reservoirs of Vibrio cholerae. Vaccine 38:A52-A62

Jubair M, Jr MJG, Ali A (2012) survival of Vibrio cholerae in nutrientpoor environnments is associated with a novel «persister » phenotype. PLoS ONE 7(9):1-8

Jubair M, Atanasova KR, Rahman M, Klose KE, Yasmin M, Yilmaz O, Jr MJG, Ali A (2014) Vibrio cholerae persisted in microcosm for 700 days inhibits mobility but promotes biofilm formation in nutrient-poor lake water microcosms. PLoS ONE 9(3):1-8

Kaas RS, Ngandjio A, Nzouankeu A, Siriphap A, Fonkoua MC, Aarestrup FM, Hendriksen RS (2016) The Lake Chad Basin, an Isolated and Persistent Reservoir of Vibrio cholerae O1: A Genomic Insight into the Outbreak in Cameroon, 2010. PLoS ONE 10:1-12

LeChevallier M W (2003) Conditions favouring coliform and HPC bacteria growth in drinking water and on water contact surfaces, In Bartram J, Cotruvo J, Exner M, Fricker C, Glasmacher A, eds. Heterotrophic plate count measurement in drinking water safety: The significance of HPCs for water quality and human health, IWA Publishing, London

Mary P, Buchet G, Deives C, Hornez J-P (2001) Growth and survival of clinical versus environmental species of Aeromonas in tap water. Int J Food Microbiol 69(3):191-198

M'Biandoun M, Guibert H, Olina J P (2003) Caractérisation du climat dans quatre terroirs en région soudano-sahélienne du NordCameroun et conséquences pour l'agriculture. In Jamin J Y, Seiny Boukar L, Floret C (2003) Savanes africaines : des espaces en mutation, des acteurs face à de nouveaux défis. Actes du colloque, mai 2002, Garoua, Cameroun. https://hal.archives-ouvertes.fr/hal00131518/document. Accessed 23 March 2018

McGuire M J (2018) Drinking water chlorination: a review of U.S. disinfection practices and issues, American Chemistry Council, Washington, DC, USA

Messi P, Guerrieri E, Bondi M (2002) Survival of an Aeromonas hydrophila in an artificial mineral water microcosm. Water Res 36:3410-3415

Momba M and Azab El-Liethy M (2017) Vibrio cholerae and Cholera biotypes. In: JB Rose and B Jiménez-Cisneros (eds) Global Water Pathogens Project. ttp://www.waterpathogens.org (A Pruden, N Ashbolt and J Miller (eds) Part 3 Bacteria) http://www.waterpatho gens.org/book/Vibrio Michigan State University, E. Lansing, MI, UNESCO

Nanfack NAC, Fonteh FA, Payne VK, Katte B, Fogoh JM (2014) Eaux non conventionnelles: un risque ou une solution aux problèmes d'eau pour les classes pauvres. Larhyss J 17:47-64

Ndongo B, Lakombouendeu S, Hiregued JP (2015) Impacts sociosanitaires et environnementaux de la gestion des eaux pluviales en milieu urbain sahélien : cas de Maroua. Cameroun. Afrique Sci 11(1):237-251

Ngnikam E, Mougoue B, Tietche F (2007) Eau, Assainissement et impact sur la santé : étude de cas d'un écosystème urbain à Yaoundé. Actes des JSIRAUF, Hanoi, pp 1-13

Ngwe E, Banza-Nsungu A B (2007) Les déterminants socio-environnementaux de la morbidité diarrhéique des enfants de moins de 5 ans en milieu urbain au Cameroun: les villes d'Ebolowa et Maroua, Projet réalisé dans le cadre du Programme international de recherche sur les interactions entre la population, le développement et l'environnement (PRIPODE) coordonné par le CICRED. http://pripode.cicred.org/IMG/pdf_CM1-FinalRepor t.pdf. Accessed 15 January 2017

Pandit AB, Kumar JK (2013) Drinking water disinfection techniques. CRC Press Taylor and Francis, New-York, USA

Serrano C, Romero M, Alou L, Sevillano D, Corvillo I, Armijo F, Maraver F (2012) Survival of human pathogenic bacteria in different types of natural mineral water. J Water Health 10(3):400-405

Sighomnou D (2004) Analyse et redéfinition des régimes climatiques et hydrologiques du Cameroun : perspectives d'évolution des ressources en eau, Thèse de Doctorat, Université de Yaoundé I, Cameroun

Soppe AIA, Heijman SGJ, Gensburger I, Shantz A, Halem DV, Kroesbergen J, Wubbels GH, Smeets PWMH (2015) Critical parameters in the production of ceramic pot filters for household water treatment in developing countries. J Water Health 13(2):587-599

String G, Domini M, Mirindi P, Brodsky H, Kamal Y, Tatro T, Johnston M, Badr H, Lantagne D (2020) Efficacy of locally-available cleaning methods in removing biofilms from taps and surfaces of household water storage containers. NPJ Clean Water 3:13. https ://doi.org/10.1038/s41545-020-0061-y

UN-Habitat (2001) Cities in a globalizing world: global report on human settlements, Earthscan Publications Ltd, London

UNICEF (2013) Choléra, épidémiologie et réponse factsheet Cameroun. https://www.unicef.org/cholera/files/UNICEF-Cholera_Facts heet-Cameroun-VF.pdf. Accessed 21 April 2018

UNICEF (2016) Cholera outbreaks in central and west Africa: 2016 Regional Update- week 22. http://plateformecholera.info/index .php/departments/wca-cholera-update/2016-bulletins/263-chole ra-outbreaks-in-central-and-west-africa-2016-regional-updat e-week-22. Accessed December 2017

Valenzuela M, Lagos B, Claret M, Mondaca MA, Pérez C, Parra O (2009) Fecal contamination of groundwater in a small rural dryland watershed in central Chilean. J Agric Res 69(2):235-243

Vital M (2010) Growth of pathogenic bacteria in freshwater and their competition with the autochthonous bacterial flora. Thèse de Doctorat, Université de Vienne, Autrich

Wang Y, Hammes F, Boon N, Egli T (2007) Quantification of the filterability of freshwater bacteria through $0.45,0.22$, and $0.1 \mu \mathrm{m}$ pore size filters and shape-dependent enrichment of filterable bacterial communities. Environ Sci Technol 41:7080-7086

WHO (2011) Guidelines for drinking-water quality, 4th edn. Switzerland, Geneva

WHO (2013) Directives pour l'utilisation sans risque des eaux usées, des excrétas et des eaux ménagères, vol 2, Genève, Suisse. http:// apps.who.int/iris/bitstream/handle/10665/78280/9789242546 828_fre.pdf;jsessionid=5F628632789F77CFD14A101F7A7D7A A8? sequence $=1$. Accessed 14 March 2016

Zoua W, Djaouda M, Maïworé J, Liang S, Nola M (2020) Scarcity of potable water and sanitation facilities in the endemic cholera region of North Cameroon. J Environ Pollut Hum Health $8(1): 6-19$

Publisher's Note Springer Nature remains neutral with regard to jurisdictional claims in published maps and institutional affiliations. 